\title{
O MUNDO MODERNO E O ESPAÇO: APRECIAÇÕES SOBRE A CONTRIBUIÇÃO DE HENRI LEFEBVRE.
}

\author{
Anselmo Alfredo*
}

\section{RESUMO:}

Trata-se de estabelecer uma análise possível da necessária relação entre o mundo moderno e as determinações espaciais para a efetivação do mesmo. Destaca-se o fato de que, na modernidade, expressa pela ampliação, em seus mais distintos sentidos, do mundo da mercadoria, os processos relativos à reprodução social serem postos e repostos pelas determinações da simultaneidade, efetividade do espaço, em detrimento das relações de sucessão, efetividade do tempo. Desta maneira, o trabalho aqui exposto destaca o papel das mediações e abstrações sociais concretizadas como espaço, tornando este uma problemática tanto social quanto analítica. A análise sobre a mesma, elevada ao plano conceitual analítico, está exposta ao longo do pensamento de Henri Lefebvre, sendo $A$ produção do espaço um momento privilegiado desta sua reflexão. Procura-se, então, destacar a compreensão de Henri Lefebvre sobre a modernidade, levando-se em consideração sua imprescindível contribuição a respeito da categoria de espaço.

PALAVRAS-CHAVE:

Modernidade, abstrações concretas, mediações, simultaneidade, espaço e Henri Lefebvre.

ABSTRACT:

This work deals with a possible analysis about the necessary relation between the modern world and the spatial determinations to effective this very world. It is enlighten that, in modernity, expressed by the enlargement of the merchandise world in so many ways, the process related to the social re-production are placed and replaced by simultaneity determinations, space effectiveness, better than succession determinations, time effectiveness. In this way, the work enlightens the role of the social mediations and abstractions that became concrete as space. So that, space realises itself such as social as well as analytical problematic. The analysis of this problematic touches both the analytical and the conceptual level what is explained along of Henri Lefebvre's thought. The Production of the Space is a privileged moment of his reflection. It is aimed to comment the Henri Lefebvre's apprehension about modernity, so, considering your indispensable contribution concerning space category.

KEY WORDS:

Modernity, concrete abstractions, mediations, simultaneity, space and Henri Lefebvre 
Pontuar o início do que se denomina mundo moderno certamente nos traz uma tarefa de difícil realização. A divergência sobre tal gênese é passível de apreciação na pluralidade de momentos históricos mencionados como ponto de partida disto que se constitui como processo $^{1}$.

O próprio (logos), a razão grega, para citarmos um quadro o mais exponencial destas distinções, já foi considerado como historicamente possível na medida em que relações modernas permitiam pensar o mundo de forma abstrata. Deste ponto de vista, formas de sociabilidade modernas se expressam na desmitologização do mundo grego como razão filosófica. Alfred Sohon Rethel (s/d), apontou tal possibilidade - da razão abstrata como expressão da gênese da modernização - como resultante de relações que se davam num mundo já monetarizado, ainda que circunscrito, constituindo, o dinheiro, não só uma abstração, mas também uma necessidade de se estabelecer o pensamento abstrato como integrado à reprodução desta sociabilidade. "Explicamos que os conceitos filosóficos puros ganharam forma historicamente no caminho pelo dinheiro, e vemos nesta opinião a alternativa histórico-materialista à tradição históricaespiritualística do idealismo, que quer explicar a gênese dos conceitos pelo caminho do pensamento" (SOHON-RETHEL, s/d, p.44). Deste ponto de vista, a relação entre as comunidades e a natureza não mais se estabelecia de forma direta, mas pela troca e pelo dinheiro. O pensamento abstrato se faz presente como razão filosófica. O metal monetário aponta-se, neste contexto, como condição e resultado genético de uma sociabilidade abstrata e, sob a perspectiva do autor, moderna.

O fato é que, mesmo de forma nunca evolutiva ou linear, mas com interrupções, recuos, saltos, violências explícitas ou incorporadas como naturalidade - expressão de contradições internas e externas às realidades postas - a realização de uma sociabilidade estabelecida por parâmetros e medidas abstratas, constituindo a própria abstração como elemento e medida do processo, como identidade contraditória daquilo mesmo que se faz como moderno, estabelece-se, temporal e contraditoriamente, através da incorporação de uma materialidade renovada e redobrada sobre si como acumulação - não se trata aqui da acumulação capitalista, ao que pese a sua importância no decorrer desta exposição -. Acumulação de temporalidades, de relações, de objetos, de experiências que, mantidas ou não neste aqui e agora como conhecimento das mesmas, integram, como síntese, a dinâmica deste isto é como isto sendo. Assim, pode-se delinear, do ponto de vista da análise, momentos deste redobrar sobre si do que temos, por ora, considerado como acumulação.

Um outro momento definido como gênese do mundo moderno se refere às grandes navegações, que passam a ser consideradas, sob diferentes enfoques, senão uma das gêneses do mundo moderno, ao menos um dos momentos deste redobrar sobre si de um processo modernizante, a partir das quais, o gestar de uma nova realidade passa a se apresentar como dinâmica presente em seu devir, síntese contraditória expressa na sua versão temporal.

Temporalidades - as grandes navegações - que nos toca sob particular interesse na medida em que estabelecem a gênese do processo civilizatório americano, integrado ao plano da modernização efetivada em sua extensão mundial. O debate sobre a presença do feudalismo ou da gênese americana como, desde o princípio, moderna ${ }^{2}$, revela a importância e presença do moderno como parâmetro de compreensão dos fenômenos presentes e, ainda mais, como ponto de apoio, ainda que movente, certamente, para a análise do mundo presente como processo redobrado sobre si mesmo. O moderno como gênese da formação americana, a partir do século XVI, está fundamentado na tese de que a América Portuguesa relacionava-se, à sua maneira, com a reprodução do mundo da mercadoria, efetivado pelas grandes navegações. O sentido da colonização ${ }^{3}$, exposto por Caio Prado J r., não 
deixa de revelar esta abstração determinante da formação americana.

Se, neste brevíssimo percurso, apontamos a abstração como elemento identitário do moderno, em suas diferentes versões, expressas em diferentes quadros temporais, é, sem sombra de dúvidas, a Revolução Industrial o momento a partir do qual a modernização e o moderno se tornam realidades empiricamente incontestáveis. Seja sob o enfoque reduzido referente ao desenvolvimento tecnológico, seja sob a perspectiva do estabelecimento de uma forma de sociabilidade universal onde o desenvolvimento das forças produtivas detém um papel fundamental. Ainda mais, ao que nos parece, o acento dado sobre a modernização a partir deste período não só não desconsidera a possibilidade e a pertinência de tomá-lo sob aqueles e tantos outros momentos, como aponta o mesmo como referência e relação possível de contraposição ao hiato que a prémodernidade representaria numa perspectiva temporal linear. A Revolução Industrial, sem desconsiderar elementos de moderno em momentos e quadros distintos, ao mesmo tempo em que compõe a análise das condições históricas que a tornaram possível - o período colonial como sendo o momento da acumulação primitiva para a Revolução Industrial, por exemplo, destacando-se, portanto, como sociabilidade moderna - mostra-se como o redobrar sobre si da acumulação, a tornar-se o próprio pressuposto de si mesma, efetivando um sentido particular de acumulação acumulação capitalista - e, assim, intensificando o próprio sentido de moderno.

Marx apontou a modernização como desenvolvimento das forças produtivas, tornada possível a partir dos escombros do mundo feudal, ponto de apoio de uma realidade que revoluciona sociabilidades pré-existentes ou, se as mantém, o faz sob o jugo da necessidade de reprodução da identidade do moderno mesmo. Numa expressão explícita de Marx:

"As queixas daquelas antigas crônicas são sempre exageradas, mas ilustram exatamente como a revolução nas condições de produção impressionou os próprios contemporâneos. Uma comparação dos escritos do chanceler Fortescue e de Thomas Morus torna visível o abismo entre os séculos XV e XVI. De sua idade de ouro, a classe trabalhadora inglesa caiu sem transição, como Thomt diz acertadamente, à idade do ferro." (MARX,1988, p.255).

Nesse ponto, Marx é fundamental ao mostrar que o processo de constituição de uma nova sociabilidade, talvez por o ser a moderna, se faz sob um plano temporal em que as rupturas aparecem como elos determinantes de um devir cuja particularidade se contradiz na medida em que, ao menos enquanto sentido, se faz como reprodução de si mesmo.

Tais rupturas o são não só no âmbito daquilo que se estabeleceria como reprodução pré-moderna da totalidade comunal, mas, também, como elos (contradição nos próprios termos?) que estabelecem a possibilidade própria do moderno e da modernização. Do moderno, enquanto um modo de ser e de se interagir socialmente no mundo da mercadoria e da modernização, enquanto potência que o trabalho adquire como desenvolvimento das forças produtivas, não desconsiderando a incorporação de um pelo outro. A exposição sobre o mundo moderno em Henri Lefebvre contribuirá para a compreensão deste inteirar entre moderno e modernização.

A tese, segundo a abordagem aqui expressa, posta em $A$ assim chamada acumulação primitiva ${ }^{4}$, exposição histórica de uma realidade determinada pelas formas lógicas de pensamento que se instituem como formas de sociabilidade - a abstração como medida e identidade da reprodução social como acumulação, nos termos mais acima expostos se faz conduzida pela lógica das separações, cisões. Não se trata, portanto, de uma exposição de como se deu no tempo a realização daquilo que para Marx passa a se constituir como o moderno e a modernização. 
Mas, nos termos marxianos, de expressar a materialidade de uma realidade que será subjugada pelas determinações abstratas como formas de sociabilidade universal.

A partir daí, como já apontamos, a gênese desta modernização constitui não exclusivamente, talvez não mesmo isto, o momento inicial a partir do qual podemos considerá-la enquanto tal; mas especialmente o culminar de um processo cumulativo a partir do qual se pode compreender o sentido mesmo, em tempos e momentos distintos, do que se faz enquanto moderno. Trata-se, enfim, de um ponto de chegada temporal que, para a análise, estabelece-se como ponto de partida, de recuos e avanços no sentido da análise sobre a história, especialmente porque é a partir desta ruptura revolucionária que se estabelecem todos os parâmetros possíveis de compreensão de realidades distintas. Este momento se faz, então, como uma expressão exponencial do sentido deste redobrar de acumulações. Ou seja, no mundo moderno, a própria acumulação se faz como identidade de si mesma, como forma social que se estabelece como mediação de si, sendo esta mediação o seu próprio resultado.

Sociabilidade contradizente na medida em que acumular se faz porque destitui - ao menos enquanto sentido, mas não enquanto efetividade - o presente como possibilidades. Só assim a mediação formal e abstrata tornase mediação e resultado de si mesma. Autonomiza-se enquanto referência de si a si mesma.

Henri Lefebvre destaca a potência das mediações porque se constituem como elementos fundamentais da reprodução social moderna. Em sua análise sobre as abstrações concretas observa que as mediações se destacam também pela capacidade que adquirem em "embaralhar" o fim e o meio, o original e o terminal. Neste sentido, ganham relevância primacial na reprodução e posição da modernidade. ${ }^{5}$

“L'importance de mediations (vermittlugen, chez Hegel) réelles et non seulement mentales (intelectuelles) ne peut se surestimer. Dans les mediation - de al monnaie à l'image dans les médias modernes - se déploient les propriétés à la fois matérielles et formelles des choses. Chez Hegel, la médiation ne se définit pas seulemnet par ce dont elle provient: origen cause historique, "terminus quo". Elle se défint aussi par le sens et le but, par la fin et le "terminus ad quem", mas surtout par I'operation que brouille la fin et le moyenm I'origenel et le terminal. L'outil (instrument) sert $d$ 'intermediaire (médiateur) entre l'activité et le mains du travailleur, $d$ 'un coté, les matières travaillèes de l'autre. Or, les gestes des travailleurs et les travailleurs euxmême changent, les matières de même." (LEFEBVRE, 1977,p.- 64-65).

Constituem-se, tais mediações, como abstrações, na medida em que dada autonomia é uma abstração dos pólos que necessariamente põe em relação, objetivandose a si mesma como determinação.

Neste ponto, as cisões, historicamente postas na acumulação primitiva, efetivam-se como lógica necessária para uma troca social cujo resultado é a acumulação de uma abstração que se faz como a identidade universal de tudo aquilo que ela mesma não o pode ser. As separações mediadas pelas distintas formas de propriedade: separação da indústria doméstica e do cultivo da terra (propriedade privada da terra), "A relação-capital pressupõe a separação entre os trabalhadores e a propriedade das condições da realização do trabalho." (Marx,1988, p. 252).

Destaque-se, também, a separação entre o trabalhador e seus meios de produção (propriedade privada dos meios de produção):

"O produtor direto, o trabalhador, somente pôde dispor de sua pessoa depois que deixou de estar vinculado à gleba e de ser servo ou dependente de outra pessoa. Para tornar-se livre vendedor de sua força de trabalho, que leva sua mercadoria a qualquer lugar onde houver mercado para ela, ele precisava ainda ter escapado do domínio das corporações, de seus regulamentos para aprendizes e oficiais e das prescrições 
restritivas do trabalho. Assim, o movimento histórico, que transforma os produtores em trabalhadores assalariados, aparece, por um lado, como sua libertação da servidão e da coação corporativa; e esse aspecto é o único que existe para nossos escribas burgueses da História. Por outro lado, porém, esses recém-libertados só se tornam vendedores de si mesmos depois que todos os seus meios de produção e todas as garantias de sua existência, oferecidas pelas velhas instituições feudais, Ihes foram roubados. E a história dessa sua expropriação está inscrita nos anais da humanidade com traços de sangue e fogo." (MARX,1988, p.252).

Separação do trabalho em relação ao trabalhador (propriedade privada do trabalho alheio) estabelece-se não só como elementos histórico-genéticos que constituem a possibilidade do capital enquanto sociabilidade, mas, especial e fundamentalmente, estabeleceu-se, como já se expressou, como vínculos lógicos que possibilitam uma reunião não existente a não ser por uma abstração resultante destas cisões. Abstração porque as distintas formas de segmentações aparecem univocamente expressas efetiva, aparente e contraditoriamente como divisão social do trabalho; divisão que remete à unidade.

Há que se ponderar, portanto, que a unidade posta como pressuposto e resultado do processo se faz pela e na constituição do trabalho enquanto uma categoria social, na medida em que o mesmo se estabelece, nos termos de Postone (1996), como mediação social. Isto é, o elemento, a partir do qual a unidade das diferenças aponta-se como passível de estabelecer uma equidade intercambiável e, assim, uma abstração em sua efetividade, isto é, abstração como sociabilidade.

A condução do processo como modernização se faz, portanto, a partir de uma acumulação de abstrações, deve-se considerar a importância que o trabalho enquanto categoria temporalmente definida e, portanto, não trans-histórica, adquire como este elemento, a partir do qual o capital se torna, contraditoriamente, uma efetividade. Fala-se, enfim, da modernização enquanto um processo universal, na medida em que ela é a constituição do trabalho como abstração cujo sentido é a realização de mais trabalho, acumulação identitária da modernidade posta pela e na modernização.

O redobrar desta acumulação, retomemos o tema inicial sobre o moderno e a modernização, como acumulação, abstração do todo em uma forma lógica, repõe o moderno como determinado pelo abstrato, mas estabelece, nesta equação tautológica, a mera, a simples identidade entre começo e fim, na medida em que acumular é o pressuposto e resultado de uma sociabilidade que, por isso mesmo, vê sua finalidade se efetivar na e como realização de suas mediações.

Não se trata, portanto, de as mediações constituírem elementos a partir dos quais os termos por elas referenciados tomem contato e efetivem uma certa dinâmica por elas regulada, mas sim, no mundo moderno, de as mediações se colocarem, contraditoriamente, como finalidade e efetividade de si mesmas. Abstração de si como mediação e reposição da abstração como identidade do moderno?

Retomemos o ponto que fundamenta a análise de Marx sobre o mundo moderno, isto é, em sua análise do capital enquanto uma sociabilidade fundamentada pelo trabalho, categoria social e analítica. Em outros termos, as cisões gestadas como elementos lógicos que estabelecem a possibilidade do moderno o fazem na medida em que a reunião, a religação se o fará pelo trabalho em sua divisão social. Contudo, como bem o sabemos, tal religação não se faz como uma simples forma de integrar o disperso, mas, especialmente, porque nessa forma posta como trabalho, a atividade social substitui a desigualdade de suas formas concretas na equivalência das mesmas como tempo de trabalho, efetivado como determinada quantidade de trabalho socialmente necessário e expresso em sua forma monetária como 
equivalente geral.

A acumulação do moderno, portanto, fazse como acumulação de trabalho - abstração historicamente determinada - definindo-se aí o sentido e, ainda mais, a determinação da sociabilidade posta na forma d' $O$ capital, isto é, num contínuo e pretensamente ininterrupto processo de reprodução ampliada do trabalho como mais trabalho. Neste transcurso lógicotemporal, Marx vê a contradição posta nesta categoria a partir da qual se torna possível estabelecer a compreensão de uma dinâmica que escapa à tautologia do trabalho como mais trabalho. Desnecessário, aqui, rescrever a contradição entre capital e trabalho. Fiquemos, brevemente, com a resultante da mesma, isto é, com aquela sociedade antevista por Marx como sendo o capitalismo da Grande Indústria, cuja análise se faz como exposição do sentido que o mais trabalho toma como mediação e finalidade da sociabilidade posta pela forma d' O capital. Isto é, a destituição do próprio trabalho da dinâmica reprodutora do moderno.

Não se trata, também, de re-elaborar a tese sobre a redução do tempo de circulação do capital enquanto capital circulante ${ }^{6}$, mas de, especialmente, destacar que a efetivação, em sua máxima possibilidade, do pressuposto do capital como aquilo que lhe é posto, repõe a necessidade de se pensar a co-presença dos momentos lógicos do capital, mas que induzem sua dinâmica histórica como restrição do próprio tempo, o que exige, neste sentido, uma necessidade da compreensão da dimensão espacial que a modernização adquire.

O plano lógico-formal da realidade estabelecida pela forma valor tem esta potência de, enquanto abstração, reduzir os momentos dispersos na condição de unidade da/na reprodução do valor. Deste ponto de vista, a unidade posta do capital enquanto momento reflete a dimensão espacial do processo efetivado desde sua gênese histórica, mas implica também em uma gênese que apresenta as suas determinações lógicas. Deste ponto de vista, Henri Lefebvre aponta a possibilidade de se pensar o espaço como abstração concreta no sentido de que a lógica posta na realização da forma valor, como redução do antes e do depois a um só momento, determinação, ao que parece, das mediações enquanto que abstrações, efetiva o próprio espaço enquanto categoria analítica e social.

Deste ponto de vista, a abstração espacial posta como necessidade lógica da reprodução do moderno, simultaneidade fundamentada pelo valor-trabalho, concretizase na medida em que se põe como forma de sociabilidade reprodutora da forma valor. Daí a tese de que o espaço social é, ao mesmo tempo, abstrato e concreto, redução do tempo ao espaço: " Cet espace serit-il abstrait? Oui, mais il est aussi "réel", comme la marchandise et I'argent, ces abstractions concrètes. Serait-il concret? Oui, mais pas de la même façon qu' un objet, un produit quelconque. (...)"(LEFEBVRE, 2000, p.-35-36). ${ }^{7}$

\section{Pós-modernismo e o problema espacial}

Esta tese, aliás, segundo a compreensão aqui pontuada, ganha dissonância em relação ao ponto de vista que Harvey (1992) acentua no moderno como a condição pós-moderna. Há, certamente, um aporte em comum que se deve ressaltar em relação ao tempo e ao espaço, na medida em que Harvey (1992) destaca a preocupação metodológica em considerar a compreensão e análise do espaço e do tempo como integrantes a uma dada sociedade, ou seja, não se pode considerar tais categorias a não ser pela materialidade social que faz das mesmas uma forma específica de existência. O que implica em múltiplas noções efetivadas entre tempo e espaço. Como explicita o autor:

“ Considero importante contestar a idéia de um sentido único e objetivo de tempo e de espaço com base no qual possamos medir a diversidade de concepções e percepções humanas. Não defendo uma dissolução total da distinção objetivo-subjetiva, mas insisto em que 
reconheçamos a multiplicidade das qualidades objetivas que o espaço e o tempo podem exprimir e o papel das práticas humanas em sua construção." (HARVEY,1992, p. 189).

O ponto, contudo, ao que pese o tributo do autor à noção de espaço e de produção de espaço de Henri Lefebvre, é o da torção no modo de estabelecer o sentido do espaço como realidade empírica e analisável no processo social. Ao que parece, Harvey (1992) destaca as distintas formas de percepção intersubjetivas de espaço que ganhariam uma dimensão significativa em sua própria constituição enquanto categoria analítica. A partir daí pode-se observar uma certa coincidência entre o que o autor chama de concepções espaciais e aquilo que para Henri Lefebvre ganha força como prática espacial. Não se trata, portanto, ao modo de Pritchard (s/d) ao analisar o tempo e o espaço Nuer, retomado por Harvey (1992), de compreender tais categorias como elementos que passam a ter presença e determinação na reprodução a partir de uma ou várias concepções subjetivas, grupais ou sociais dos mesmos; mas de estabelecer a distinção entre aquilo que se efetiva como determinação espacial na reprodução social e como que as mesmas torcem-se como formas ilusórias a se estabelecerem distintas do que são como subjetividade. Se a análise de Harvey é válida e obtém importância a partir das comunidades Nuer, ou das comunidades indígenas americanas, o fulcro da tese lefebvriana sobre o moderno a partir do espaço é exatamente compreender a distinção que estas noções ganham no interior da reprodução e como reprodução do mundo da mercadoria. Desta maneira, Haussmann e Le Courbusier não se constituem como sujeitos redefinidores do espaço, a partir do que " temos, forçosamente que ajustar as nossas práticas diárias “ (HARVEY,1992,p.190), mas sim que introjetam, como subjetividade, o espaço como saber, concepção cuja lógica abstrata se expressa como uma necessidade da reprodução de um modus operandi social onde os sujeitos transfiguram essa racionalidade como mera subjetividade e/ou capacidade. A análise de Harvey (1992), contudo, mostra a sua pertinência no momento em que analisa a importância de uma realidade que constitui o percebido através de imagens que introjetam, objetivamente, a representação de uma subjetividade, cuja resultante é a reprodução daquilo mesmo que o cidadão americano está discorde. É assim que Harvey (1992) expõe a potência das representações lefebvrianas na reprodução da relações sociais de produção, vistas do ponto de vista do político. Tatcher e Reagan aparecem como expoentes destas representações na análise do autor.

Se se trata de uma análise do moderno, como condição da pós-modernidade, a partir do tempo e do espaço, torna-se necessário uma distinção entre essas duas categorias para que se possa estabelecer a relação posta entre as mesmas num dado processo social. Ao se colocar este problema para Harvey (1992), o percurso exposto se apresenta pela distinção entre o vira-ser, como identidade do tempo, e o ser, como identidade do espaço, tese aliás, muito próxima daquela exposta por Santos $(1977)^{8}$, onde a formação econômico social efetiva-se como espaço, daí a tese de formação sócio-espacial, enquanto que o modo de produção ainda abstrato refere-se ao tempo, por que não realizado - noção de abstração exposta por Santos (1977) nesse trabalho.

Harvey (1992) destaca esta distinção na medida em que observa a identidade da modernidade com o progresso, o que permitiria um destaque, um prevalecimento da abordagem temporal, do vir-a-ser, em detrimento do ser, no espaço e no lugar (HARVEY,1992, p.190), estabelecendo, no ato da crítica teórica, o seu ponto de vista a respeito da identidade que se efetiva como tempo e como espaço. O paradoxo apontado pelo autor é justamente o de as formas de representações (fotos, cartogramas, etc.) não serem suficientes para - enquanto espaço que são, pois que se tratam de um dado tempo $t$, como um aqui e agora - envolverem a fluência da velocidade posta como mundo 
moderno. Como pergunta o autor: “Até que ponto são adequados esses modos de pensamento e esses conceitos diante do fluxo da experiência humana e dos potentes processos de mudança social? “ (HARVEY,1992.p.191). Questão que deriva para o seguinte questionamento: não estaria, aí, o autor ressaltando, uma vez mais, os processos exclusivamente temporais, já que um dado instante (dimensão temporal) é tomado como identidade do espaço? Sejamos, de modo saudável, provocativos; não estaríamos, em verdade, incorrendo na indistinção entre tempo e espaço que obscurece a importância das determinações espaciais no mundo moderno? Se sim, aliás, isto terá conseqüências na análise do autor a respeito do que considerou como próprio da modernidade e condição da pós-modernidade, ou seja, a compressão do tempo e do espaço, ou, mais polêmico ainda, a compressão, pelo tempo, do espaço. Mas caminhemos o passo anterior...

Certamente, a redefinição posta na vivência e na efetividade do tempo e do espaço no mundo moderno tem nos permitido uma necessária reflexão sobre os mesmos. A relação estabelecida entre tais categorias tem sido objeto de diferentes abordagens. Milton Santos, em seu trabalho sobre a Nova Geografia, destaca não só a necessidade de uma ciência do espaço, como a importância de se considerar a noção de tempo-espaço como algo indissolúvel.

"Tudo o que existe articula o presente e o passado, pelo fato de sua própria existência. Por essa mesma razão, articula igualmente o presente e o futuro. Desse modo, um enfoque espacial isolado ou um enfoque temporal isolado são ambos insuficientes. Para compreender uma qualquer situação necessitamos de um enfoque espaçotemporal. A lógica do tempo, escreveu Anuchin $(1973$, p.52) reúne os dois aspectos da existência da matéria, isto é, tempo e espaço (SANTOS, 1978,p.203)." [E mais à frente expressa]: "é no espaço que uma atualidade se dá " (SANTOS,1978, p.204). É oportuno destacar aqui o reconhecimento de Milton Santos em relação à importância de Henri Lefebvre na problematização do espaço e de sua produção para a compreensão dos processos sociais: "Todas as tentativas de explicar o espaço subtraíram praticamente o problema chave de sua produção, a grande exceção vindo de $H$. Lefebvre (1973)." (SANTOS, 1978, p.161).

Ainda que aqui reencontremos a diferença entre tempo como devir e o espaço como um aqui e agora, trata-se de considerar o desafio posto pelo mundo moderno. Em outros termos, para Milton Santos o espaço também é objeto da simultaneidade posta como resultado do mundo moderno, do que deriva a tese sobre o espaço como acumulação desigual de tempos (SANTOS, 1978,p.209). A partir disto, em sua obra A natureza do Espaço (SANTOS,1996), considera o espaço como um sistema indissociável entre objetos e ações justamente porque as técnicas permitiriam realizar o tempo como espaço, constituindo a idade do lugar, na medida em que elas efetivariam este acúmulo desigual de tempos, constituindo-se um sistema específico de realização temporal e simultâneo que se faz como espaço. A noção de que o espaço retém tempos, deriva, em Santos (1996), deste raciocínio. O problema posto, segundo a apreciação aqui exposta sobre o autor, é o fato de o espaço ser aquela identidade presentificadora do tempo ${ }^{9}$, onde a abstração freqüentemente estaria referida à dimensão temporal e a concretude ao espaço porque o presente. Suscita-se aí, levado o raciocínio ao extremo, uma impossibilidade de se pensar não só as abstrações espaciais como o próprio espaço abstrato. Dado que ao espaço cabe esta identidade concreta e concretizante, indistinguem-se as representações espaciais como uma forma de ser e de apresentação do próprio espaço e, portanto, o espaço, como representação de concreticidade; ao não ser assim discernido na análise, é tomado pela sua representação como se somente espaço concreto fosse. Tributo custoso ao pensamento materialista ao exigir de si como pensamento científico uma necessidade de se pensar as dimensões concretas da realidade posta. Neste aporte do e sobre o real, as determinações concretas das abstrações são tomadas como 
uma idealidade que se confunde como idealismo. A ruptura deste marxismo com a idealidade hegeliana dispensou a análise das abstrações para a compreensão do moderno e da modernidade, como se a referência científica a elas fosse algo que desprestigiasse a noção de materialismo e ou materialidade, o que suscitou a não compreensão das determinações metafísicas da sociabilidade sob a forma do capital $^{10}$. A partir daí, científico confunde-se com o material, o concreto, partido de suas determinações metafísicas. É a este falso desprestígio que se justifica, então, a importância do espaço, pois a ele são referenciados os atributos do materialismo que justificariam a análise não idealista do moderno, como se as determinações metafísicas do real na sua forma social capitalista não guardassem a problemática sob o moderno a ser desvendada. Enfim, o engodo do mundo moderno passa a se estabelecer como se explicação dele fosse.

Cabe ainda ressaltar que a primazia dada ao mundo das técnicas dá a este um estatuto cuja análise põe o real a confirmar a verdade das categorias propostas, estabelecendo-se o seu percurso teórico mais como uma preocupação em construir uma razão axiomática do que explicitar o real a partir de categorias a ele pertinentes, inversão que coincide com a do próprio sentido do conhecimento em sua versão científica. Mas o ponto que nos parece fundamental nas distintas análises que por ora nos ocupa é a busca de articular a importância do espaço num momento em que o capitalismo, enquanto uma reprodução social global, ganha formas qualitativamente novas de reprodução no interior de sua própria condicionante histórica, ressaltando, de acordo com o nosso argumento neste pequeno trabalho, a relação e importância entre o espaço e o mundo moderno, o que aliás nos permite retomar o diálogo com Harvey (1992).

Para este último, o ponto que expressa uma diferenciação do espaço - no sentido de uma postura materialista - no e como mundo moderno está transposto na crescente velocidade do tempo, dada pela circulação do capital cuja rotação, historicamente, deve se efetivar cada vez mais rapidamente. Sob esse prisma, Harvey (1992) aponta uma necessária aceleração, na modernidade capitalista, do ritmo dos processos econômicos e da vida social, do que deriva uma necessidade de se ultrapassar as barreiras espaciais (HARVEY, p. 210-212), contraditoriamente, através da produção de um dado espaço (HARVEY,1992, 234), mas cuja resultante é a compressão do tempo e do espaço a partir da modernidade, como condição do pósmoderno. Na afirmativa do autor:

“ Como os usos e significados do espaço e do tempo mudaram com a transição do fordismo para a acumulação flexível? Desejo sugerir que temos vivido nas duas últimas décadas uma intensa fase de compressão do tempo-espaço que tem tido um impacto desorientado e disruptivo sobre as práticas político-econômicas, sobre o equilíbrio do poder de classe, bem como sobre a vida social e cultural." (HARVEY,1992, p.257).

$\mathrm{Na}$ relação necessária entre tempo e espaço, - tomada por Santos (1977) o espaço, como o aqui e agora, constitui-se como uma acumulação desigual de tempos e, por Harvey (1992), como um processo cuja resultante é a compressão espaço-temporal - torna-se necessário, para este último autor, uma pergunta. Se o sentido é desta compressão, quando de sua efetividade, o que resta? Uma sociedade a-temporal e a-espacial? Caberia, portanto, pensada nesses termos, a possibilidade da pós-modernidade? E, agora, uma outra derivação... Se o espaço é o elemento relativo ao ser e não ao devir, como derivar daí as determinações espaciais do mundo moderno? Seria o espaço apenas um problema relativo às representações, nos termos abordados pelo próprio Harvey (1992)? Aliás, este talvez seja um dos caminhos possíveis de se compreender o sentido desta compressão, pois, segundo a compreensão aqui exposta, a noção de crise de representação do espaço para Harvey (1992) refere-se mais ao problema relativo às representações estéticas, subjetivas ou de um dado espírito da época, como o caso 
do Iluminismo abordado pelo autor, o que, segundo o nosso entendimento, difere bastante da forma pela qual Henri Lefebvre irá abordar as representações do espaço em sua tríade ${ }^{11}$, destacada aliás pelo próprio Harvey (1992).

Harvey, contudo, toca num ponto que, segundo o argumento destacado ao longo deste trabalho, é fundamental, qual seja: a aceleração do tempo está posta pela velocidade de reprodução do próprio capital, sendo a noção de rotação do capital, destacada por Marx (1997) e retomada por Harvey (1992), o momento fundamental para a compreensão do processo. Contudo, o problema posto por Marx é que o capital enquanto conceito realizado, mesmo que ilusoriamente, realiza-se, nesta aceleração do tempo, como tempo zero de circulação, donde a unidade do conceito recorre sem tempo, ou então, como tempo zero. Por que, portanto, derivar daí, a compressão do espaço, e não a posição de suas determinações no mundo moderno, mais do que as do tempo, dado que a simultaneidade ocorre de modo mais efetivo? Em outras palavras, esta velocidade temporal, em sua necessária relação com o espaço, não só adquire um sentido quantitativo, mas redefine qualitativamente o tempo efetivando a reprodução do moderno a partir das determinações espaciais, isto é, a partir da simultaneidade como elemento fundamental para a reprodução da modernidade enquanto um modo de produção no sentido amplo, isto é, que envolve a produção e reprodução social. Harvey (1992), portanto, segundo o ponto de vista aqui exposto, evita o confronto teórico necessário para compreender a importância da análise sobre a reprodução do moderno a partir das determinações espaciais, na medida em que o espaço e o tempo, enquanto objetos de sua análise, tendem à compressão. Harvey (1992) mesmo aponta, ao final de sua obra, a possibilidade de a pós-modernidade ser uma representação de um mesmo fluxo social temporal, isto é, da pós-modernidade ser uma máscara do moderno, demonstrando, segundo o nosso ponto de vista, uma interrogante que se exerce como auto-crítica em relação a sua tese sobre o problema relativo à compressão.
Ao analisar as distintas respostas sobre o problema assim observa o ponto de vista de Virilio e Baudrillard:

"A quarta resposta tem sido tentar montar no tigre da compressão do tempo-espaço mediante a construção de uma linguagem e de imagens capazes de espelhá-la e, quem sabe, dominá-la. Eu ponho os escritos frenéticos de Baudrillard e Virilio inclinados a fundir-se com a compressão do tempo-espaço e a reproduzi-la em sua própria retórica extravagante." (HARVEY, 1992, p.316).

E ainda faz a seguinte observação de que há: "Um reconhecimento de que as dimensões do espaço e do tempo são relevantes, e de que há geografias reais de ação social, territórios e espaços de poder reais e metafóricos..." (HARVEY,1992, p.321).

Falamos mais acima de uma mudança qualitativa do tempo e espaço, justamente porque na aceleração temporal as determinações da simultaneidade passam a ser preponderantes àquelas relativas à diacronia, o que nos remete à problemática espacial. A necessidade, acentuada pelo próprio Harvey (1992), de uma produção espacial (ferrovias, telégrafos, rodovias, etc.) não seria exatamente a expressão de uma exacerbação das dimensões espaciais em detrimento do tempo, dado a historicidade do próprio capital?.. O ponto fulcral, talvez, seja exatamente explicitar porque, neste momento, não se trata, a simultaneidade, de algo relativo apenas ao tempo, pois que se refere a uma mudança qualitativa do tempo que se configura como espaço. Isto implica dizer que a aceleração temporal é um outro modo de dizer sobre a sua supressão, ao menos como sentido, e, assim, num adensamento de temporalidades diversas e co-presentes cuja efetividade é a própria sobreposição das determinações espaciais no mundo moderno. O adensamento temporal é a determinação espacial do tempo. Não importa aqui se a exposição se faz de modo metafórico, mas sim que o problema nos está posto. O ponto é que, nesta simultaneidade lógica e prática, a sua realização enquanto forma de sociabilidade 
se torna efetiva também na medida em que posta como aquele espaço visível e produzido, no sentido da Produção do Espaço, tomado por Lefebvre (2000). Daí ter-se aqui destacado uma certa contradição no argumento de Harvey (1992) a respeito da compressão espacial justamente quando da necessidade de se produzir um espaço através das ferrovias, telégrafos, etc. Trata-se de um adensamento temporal que se efetiva como espaço, como já se pontuou. Esta compreensão, defende-se aqui, está expressa no pensamento de Henri Lefebvre cuja tese refere-se à impossibilidade de se analisar o mundo moderno sem que se leve em consideração as determinações espaciais de sua re-produção, resultantes de sua historicidade crítica. Daí uma apreciação mais aproximada desta discussão percorrendo algumas das obras que compõem o seu pensamento.

\section{O moderno e o espaço em Henri Lefebvre}

Quando Henri Lefebvre acentua a necessidade de se compreender a modernidade a partir da produção do espaço, levanta não só o problema relativo ao fato de que o espaço deve ser compreendido como um produto social, no qual se pode desvendar, por exemplo, a agregação de valor-trabalho, mas que se refere a uma forma social específica, a partir do qual a reprodução está posta como possibilidade crítica. Trata-se aí de uma compreensão de que a relação espaço-temporal passa a se estabelecer a partir de relações onde o antes e o depois perdem a potência de determinação. Mais do que isso, trata-se de uma realidade onde esta possibilidade temporal passa a ser contradizente, isto é, impeditiva da reprodução social moderna. Dado o seu aspecto crítico, estabelece-se uma sociabilidade supressora do tempo. Prevalece, aí, a co-presença representada como sucessão através das abstrações. Isto implica dizer que o "embaralhar" do seqüencial, pondo-se como simultaneidade, não está explícito, mas, necessariamente comparece à realidade como aquilo que ele não é. $A$ abstração dos distintos momentos como simultaneidade é a representação de uma linearidade temporal ou linearidade que, contudo e por isso, torna efetivo o espaço, simultaneidade necessária à realização crítica, e porque crítica, do mundo da mercadoria.

A sociedade que se assenta sob a reprodução ampliada da riqueza abstrata, expressa em sua forma monetarizada, tem, como pressuposto e resultado, o desenvolvimento das forças produtivas. Sob este aspecto, o próprio espaço produzido por tal desenvolvimento, no mundo moderno, é, ele mesmo, uma força que intensifica a produtividade fundamentada pela reprodução ampliada do valor. Como diz o autor:

“ Les forces productives (nature, travail et organisation du travail, techniques et connaissances) et bien entendu les rapports de production, ont un röle - à déterminer - dans la production d'espace"(LEFEBVRE, 2000, p.57) ${ }^{12}$.

Henri Lefebvre de forma consciente defende, portanto, a tese de que mais do que em qualquer outra forma de sociabilidade prémoderna, na modernidade, o espaço passa a se constituir numa categoria fundamental para a compreensão e análises de fenômenos e processos a ela inerentes. Trata-se, enfim, de compreender não exclusivamente o papel do espaço nesta reprodução, o que nos remeteria a uma leitura funcionalista do mesmo, mas as determinações espaciais na constituição, produção e reprodução do mundo moderno.

Se, na fundamentação do próprio autor, a cada modo de produção corresponde um espaço específico, cabe-nos desvendar o espaço da e na modernidade enquanto uma categoria filosófico-analítica. Deste ponto de vista, as contradições não se limitam a se constituírem como contradições relativas ao tempo, mas, na modernidade, tratam-se, fundamentalmente, de contradições espaciais, dada a redução, já mencionada, do tempo ao espaço.

Se há, por assim dizer, caminhos 
profícuos de análise do mundo moderno apontados por Henri Lefebvre, é a imposição do espaço como determinação da reprodução social que faz destes caminhos uma necessidade teórica emergente, o que, como contraponto, oferece-nos a não ontologização do espaço, no sentido de se estabelecer como uma categoria trans-histórica. O espaço capitalista como sendo aquele que corresponde aos nexos do processo de acumulação e reprodução do valor.

Mas, retomemos uma derivação por demais necessária no pensamento de Henri Lefebvre. É fundamental destacar que em sua leitura da obra de Marx, Lefebvre desbravou a necessidade de se compreender fenômenos e processos oriundos de uma realidade posta na formação e constituição do capital, portanto expressos e analisados por Marx, mas que tiveram seus desdobramentos posteriores, constituindo uma realidade que, categorialmente, traria elementos novos e necessários de serem inseridos na análise do moderno, mas em uma unidade analítica compreensiva, necessidade teórica explicitada em uma de suas reflexões: Vejamos esta passagem :

"um fluido único percorre o conjunto; tenho buscado restituir a teoria de Marx em toda sua integridade e amplitude empreendendo ao mesmo tempo seu aggionamento; depois de um século de grandes transformaçõe, o materialismo histórico e o dialético tão poderosos no plano teórico não podem se sustentar dogmaticamente" (LEFEBVRE, 1976, p.09) ${ }^{13}$.

A tese marxiana fundamental relativa ao desenvolvimento das forças produtivas, constituindo o fim do trabalho como determinação do próprio capital, está, segundo o ponto de vista aqui expresso, subjacente na compreensão da modernidade em Henri Lefebvre. Aliás, pode-se dizer que o próprio capital como uma lógica crítica expressa em suas contradições, constitui uma análise e compreensão do processo a partir da qual deriva-se a necessidade de questionamentos pertinentes ao mundo contemporâneo. Henri Lefebvre constrói seu pensamento tendo esta tese sempre subjacente e motora de suas reflexões sobre a modernidade.

Marx já havia derivado o raciocínio de que a concorrência entre os diferentes capitais, ao ser efetivada na contradição entre capital e trabalho, cuja resultante seria a redução do trabalho necessário, implicava, por outra via, num aumento das forças produtivas que não redundaria apenas numa mudança quantitativa. Isto é, não se tratava apenas da redução do trabalho necessário e aglomeração do capital em grandes empresas. Mas que, sobretudo, com a intensificação do desenvolvimento das forças produtivas, o trabalhador passa a ser um mero vigia do processo produtivo, dada a expropriação relativa de seu trabalho, assim, o capital, como forma social, muda em seu aspecto qualitativo.

A Grande Indústria, denominada por Marx nos Grundrisse, momento fundamental de seu pensamento, sintetiza o momento em que se é possível, portanto, realizar e pensar o trabalho no seu sentido propriamente social. O que implica numa compreensão de que as forças produtivas não mais se limitam à capacidade produtiva do que ainda o autor denomina como capital fixo. Como expressa Marx:

El trabajo ya no aparece tanto como recluido en el proceso de producción, sino que más bien el hombre se comporta como supervisor y regulador con respecto al proceso de producción mismo (MARX: 1997, p.228).

Trata-se, sim, de que, na expansão do tempo livre, aquilo que se deveria realizar como ócio é apropriado pela reprodução social como força produtiva. As ciências parcelares e o próprio pensamento nessa forma científica passam a constituir o trabalho social como força produtiva.

Isto implica na necessidade de se compreender a modernidade, no século $X X$, vivido por Henri Lefebvre, não mais exclusivamente do ponto de vista das lutas de 
classe ou do trabalho no interior do processo produtivo propriamente dito. Trata-se de analisar, enfim, a expansão do capital como generalização espaço-temporal, isto é, como incorporação dos momentos e lugares da vida social que, mesmo postos possivelmente como sua contraposição, ainda que nessa condição, passam a ser incorporados na reprodução das relações sociais do produção, Lefebvre (1973).

A questão fundamental expressa por Henri Lefebvre, derivada, segundo o argumento que se procura tecer, desta tese marxiana, é, portanto, compreender como e porque no aprofundamento das contradições postas na relação capital trabalho, justamente aí, os termos da contradição perdem a sua potência revolucionária e incorporam os sentidos da reprodução. Ao que se parece, este seria um sentido forte de modernidade esculpido por Henri Lefebvre. As separações e distanciamentos entre o homem e a natureza, Lefebvre (1969), as cisões a partir de uma unidade pré-moderna forjadas na modernidade como pertencimento, Lefebvre (1990), as divisões postas como divisão social do trabalho, Lefebvre (1980), dentre outras, contradições necessárias da reprodução social, passam a ser elementos integrados no pulsar da forma valor, apesar de e no interior da sua crise fundamental. Aquilo que é contraditoriamente necessário, apesar desta contradição posta, passa, ao longo da modernidade e, talvez, como modernidade, a ser incorporado no âmbito da extensão crítica do mundo da mercadoria. A extensão do mundo da mercadoria é resultante de suas próprias contradições.

Para Henri Lefebvre a Grande Indústria estende-se, na segunda metade do século $X X$, especialmente após a Segunda Grande Guerra, como mundo do consumo. Em outros termos, a tensão posta na contradição capital trabalho, desenvolvendo daí o fim do trabalho como possibilidade em efetivação, redobra as contradições do mundo da mercadoria para a esfera onde o consumo passa a ser determinante. Há, enfim, para o autor, uma tensão necessária de se explicitar na relação contraditória entre o aprofundamento da crise e o renovar das reproduções. Uma não se certifica sem a outra e, na vida cotidiana no mundo moderno, acentuam-se os termos da reprodução obscurecendo, no plano do percebido, a importância do ponto ou dos pontos críticos. O pêndulo da análise lefebvriana, um ponto fixado na crise e outro na re-produção, mostra, no seu movimento, a unidade contraditória dos mesmos. O mundo do consumo ou da mercadoria resulta desta dinâmica.

Não se trata, portanto e contudo, do mero consumo das mercadorias produzidas para salvar o montante de investimento no capital fixo. Trata-se sim de, na crise do mundo do trabalho, estabelecer o consumo como substituto das determinações que a esfera da produção teve na formação e reprodução do mundo capitalista. Lefebvre não se limitou a uma compreensão reduzida no sentido de que na extensão da grande indústria estava posto um problema relativo à super-produção. Não se trata de um requentar da velha, mas atuante pois que se faz como saber, economia política. Seria mais adequado reconhecer que nesta nova dinâmica - em que o trabalho não mais põe as determinações de medida da reprodução social, ou seja, no momento a partir do qual o próprio capital perde a sua medida abstrata como tempo de trabalho - o mundo do consumo deve integrar não somente o seu sentido referente à realização do salto mortal da mercadoria, mas, ao ser esta a sua particularidade na reprodução da universalidade valor deve, como consumo, realizar - de modo condensado - também os sentidos que antes estavam postos no momento da produção. Isto implica dizer que, para Lefebvre, o século $X X$ dirimiu, acirrando novas contradições e distendo outras, a distinção entre produção e consumo no consumo, revolvendo este último como produção e reprodução social. Ou seja, é no consumo que a sociedade, consumindo-se, se produz. Novas contradições? Superar de um pensamento restrito à formalidade da economia política? Restrição extremada das distinções 
seqüenciais do tempo a efetivar a simultaneidade como espaço? Reconhecimento do pensamento lefebvriano para a compreensão do mundo moderno? Cotidiano efetivado como categoria social e analítica? Fiquemos com a primeira interrogante...

A contradição capital trabalho assim posta, impõe a própria necessidade de os distintos capitais se efetivarem como tal na medida em que realizam o mundo do consumo como a esfera talvez privilegiada de investimentos. Trata-se, enfim, de produzir a esfera da circulação e do consumo como momento integrado da reprodução social. O consumo sendo determinante da totalidade, ao menos enquanto sentido. Isto implica dizer que não se trata de consumir este ou aquele objeto, esta ou aquela mercadoria, mas de estabelecer o ato de consumir como representação de algum sentido qualitativo que o mundo da mercadoria não mais repõe, a não ser como contravenção ou contraposição. Como expõe Lefebvre:

“Não é o consumidor nem tampouco o objeto consumido que têm importância nesse mercado de imagens, é a representação do consumidor e do ato de consumir, transformado em arte de consumir..." (LEFEBVRE,1991, p.64) .

Numa realidade esvaziada de conteúdos, onde o próprio trabalho concreto como necessidade para a sua abstração como tempo de trabalho perde a densidade antes existente, a extensão do mundo da mercadoria terá de se fazer como consumo de tudo aquilo que se coloca como necessidade de reprodução. Assim, o próprio consumo, enquanto forma que é, deve se representar enquanto um conteúdo que efetivamente não está posto. Trata-se, enfim, do que Henri Lefebvre considerou como a espetacularização do consumo ou espetáculo do mundo:

"O desvio da energia criadora de obras para a dramatização, para a visualização espetacular do mundo (cinema, televisão) tem suas implicações. o 'espetáculo do mundo' torna-se consumo de espetáculo e espetáculo do consumo, o que fornece um bom exemplo de torniquete, uma espécie de pleonasmo que os racionalistas da organização tomam por um equilíbrio (feedback) satisfatório." (LEFEBVRE, 1991, p. 71).

A geógrafa Ana Fani Alessandri Carlos interpreta a partir do pensamento Lefebvriano a tese de que o mundo moderno não se restringe apenas às praças ou espaços de consumo, mas da integração do próprio consumo do espaço, onde o tempo livre, produzindo o espaço do lazer sustenta a passividade do usuário posto como tal na espetacularização do mundo como e através do consumo, donde o lazer e o turismo têm um papel a se desvendar.

"O consumo do espaço se analisa no movimento de generalização da transformação do espaço em mercadoria, que impõe ao uso a existência da propriedade privada das parcelas do espaço. Assim, o processo de reprodução do espaço aponta para a tendência da troca sobre os modos de uso, o que revela o movimento do espaço de consumo para o consumo do espaço" (CARLOS, 1999, p. 186).

Fala-se, enfim, da indistinção entre significante e significado que põe o significado como auto-referência, constituindo-se o mundo moderno como um conjunto de subsistemas que se explicam tautologicamente enquanto tais. A linguagem, como subsistema auto-referencial, talvez se expresse como um exemplo exponencial da forma se redobrando para se representar enquanto conteúdo. A partir daí, onde tudo deve se realizar na forma do consumo, como necessidade da reprodução social, tudo aquilo que não corresponda a esta simultaneidade do consumo como consumo e produção pelo consumo passa a se estabelecer, objetivamente, como o dispensável, o inutilizável, aquilo que cabe e não cabe ser dito, que pode e não pode ser escrito, que deve e não deve ser integrado, o que pode e não pode sequer ser pensado..., enfim, a centralidade da forma tornando periferia a densidade dos conteúdos do viver. Trata-se da expressão mais acabada do Cotidiano enquanto modo de vida, administrado, portanto, a partir de uma lógica 
do terror, pois que eivado pela violência latente, explícita ou mesmo implícita.

“Na 'sociedade terrorista' reina um terror difuso. A violência permanece em estado latente. As pressões se exercem de todos os lados sobre os membros dessa sociedade; eles têm uma enorme dificuldade para se desembaraçar delas, para afastar esse peso. Cada um se torna terrorista dos outros e seu próprio terrorista; cada um aspira a tornar-se um terrorista exercendo (nem que seja por um momento) o Poder." (LEFEBVRE, 1991, p.158).

O Cotidiano, portanto, como sociedade burocrática de consumo dirigido é a busca de estender, de modo terrorista, o consumo como totalidade da reprodução. Evidentemente que não sem contradições, mas a partir das contradições então postas. Observe-se, contudo, que esta reflexão sobre o Cotidiano, em Henri Lefebvre, é oriunda da extensão do tempo de não-trabalho que, na reprodução das relações sociais de produção, é incorporado ao mundo da mercadoria. Ponte, passagem, vereda que não se pode perder de vista.

Assim, tempo e espaço do ócio, constituídos na sua versão crítica moderna, apresentam-se como lazer: consumo de tempo e de espaço, produção espacial para consumo de tempo e espaço que reproduzam, ainda que criticamente, as relações sociais sob a forma valor. Numa rápida exposição do autor:

"Os espaços de lazer constituem objeto de especulações gigantescas, mal controladas e freqüentemente auxiliadas pelo Estado (construtor de estradas e comunicações, aval direto ou indireto das operações financeiras, etc.)" (LEFEBVRE, 1977, p.247).

A preocupação relativa ao espaço, tomada como questão fundamental para se compreender o mundo moderno, reflete a incorporação da reprodução social como totalidade, ainda que contraditória, na medida em que a sociedade se faz e se reproduz a partir de um espaço específico. Neste sentido, o tempo dado pela sociedade enquanto forma específica de sociabilidade se faz através do espaço e a categoria espacial retém a universalidade do processo.

Não se trata de um mero discurso espacial, se é que isso se possa parecer à primeira vista, mas de compreender a determinação espacial numa sociabilidade cujo sentido, como já mencionamos, é a redução do tempo ao espaço. Trata-se, enfim, de, nesta redução, - estabelecida pelas mediações que embaralham o antes e depois como mera presentificação que, enquanto tal simultaneidade, efetivam-se como espaço desvendar as determinações espaciais desta reprodução. Daí deriva uma necessária teoria espacial em Henri Lefebvre cuja reflexão mais apurada encontra-se em La Production de I'Espace ${ }^{14}$.

Aqui pode-se considerar que Lefebvre (2000) destaca a modernidade como uma sociabilidade cuja reprodução se efetiva através de uma prática espacial. O mundo moderno como sendo aquele constituído especialmente através da realidade urbana. ${ }^{15}$ - isto pelo surgimento e crescimento das grandes metrópoles, induzidas pela industrialização ao longo do XIX e primeira metade do século $X X^{16}$ - apresenta-se como uma evidência das determinações espaciais da modernidade. Eqüivale dizer que o espaço é efetivação da simultaneidade necessária à reprodução social das relações capitalistas. Não sem motivos, Henri Lefebvre considerou a simultaneidade como aquele elemento referente à forma do urbano no mundo moderno, pressuposto necessário para a reprodução da sociedade capitalista.

Observa-se que, em realidades onde a realização do capitalismo se faz a partir da desigualdade do desenvolvimento ${ }^{17}$, a supressão da sucessão é, talvez, mais explícita como elemento necessário à realização do capitalismo, colocando ainda mais o problema relativo ao espaço. Em sua pesquisa sobre a formação das cidades na área de fronteira, cabe destacar a definição de "cidade sem infância", apontada por Sérgio Martins, donde a lógica da 
mercadoria não se estabelece numa dimensão temporal linear, mas aos saltos e simultânea aos nexos da forma. Essa supressão do uso desde a gênese, estabelece-se, num tributo expressamente lefebvriano, na realização do espaço como reprodução daquilo que está posto. Ao analisar esse processo a partir da cidade Chapadão do Sul, numa área de fronteira da expansão capitalista, observa:

“Chapadão do Sul é uma cidade que nasceu adulta porque concebida segundo uma racionalidade que passa longe da festa como sentido de apropriação, de 'consumo' da cidade pelas representações da imediaticidade da vida. As ' festas a bem da colonização', realizadas pelo próprio Fomentador, precederam a cidade. Mas, como anti-festa, elas são privadas de espontaneidade, pois provas em essência, de uma intencionalidade dada de antemão, que tem a cidade como finalidade de ser o local e o centro de consumo das Coisas, do encontro delas, e não das pessoas." (MARTINS, 1996, p.40) ${ }^{18}$.

Aprecia-se a incorporação na análise de uma compreensão sobre o mundo moderno, realizado enquanto tal, como espaço, totalidade contraditória, isto é, aberta, como devir. Nas suas múltiplas perspectivas efetivas e analíticas, o espaço se põe como o elemento que realiza o mundo moderno como totalidade, em suas formas particulares, através do e como espaço. O pensamento lefebvriano constrói-se, num dado momento exposto mais a seguir, como uma teoria espacial, vínculo flagrante com a Geografia como uma forma de conhecimento. Como observa a geógrafa:

"Abre-se assim o pensamento para a formulação de uma teoria unitária do espaço que sintetiza o natural (quadro físico), o mental (os espaços de representação e ou representações do espaço) e o social, com a prática correspondente, vista já, como prática espacial. Formula-se assim, o conceito de espaço social. Para operar com ele é preciso ir discernindo três níveis do real: o percebido, o vivido e o concebido, em cuja assincronia se apreciariam confrontos e conflitos, o movimento do devir. " (SEABRA,1996, p.09).
Em Henri Lefebvre, dado que a simultaneidade, efetividade enquanto espaço, adquire contornos no interior da teoria das formas, e passa a ser um elemento componente e necessário da reprodução social capitalista, enquanto forma, estabelece-se como elemento lógico que reduz as dimensões do possível na unidade contraditória do mundo da mercadoria. Simultaneidade, enquanto espaço, é redução da sucessão, efetividade do tempo:

"Plus que des invariances ou constances, ce passage incessant de la temporalité (sucession, enchainement) à la spatialité (simultanéité, synchronisation) définit toute activité produtrice (LEFEBVRE, 2000, p.87) ${ }^{19}$.

A realidade urbana toma uma dimensão importante no pensamento do autor justamente porque contém, de modo o mais acabado possível, este sentido do espaço como determinação do mundo presente. Henri Lefebvre distingue a cidade do urbano justamente porque considera que a forma urbana, enquanto simultaneidade, não mais pode limitar-se ao espaço da cidade. Assim, o urbano passa a integrar o Cotidiano enquanto categoria social que explicita, de forma mais acabada, o sentido da reprodução das relações sociais de produção, como já nos referimos acima. Pode-se dizer que se trata não da produção material, mas de uma produção específica, como expressa Carlos (2004).

“...Lefebvre nos coloca diante da idéia de que o modo de produção precisa se reproduzir, uma reprodução que não coincide com a produção dos meios de produção, mas se efetuaria também em outros planos, colocando-nos diante das "novas produções" capazes de explicitar o mundo moderno: o espaço, o urbano, o cotidiano (cotidianeidade)." (CARLOS, 2004, p.25).

Cabe destacar que esta abordagem lefebvriana mostra sua pertinência, pela Geografia, quando da abordagem relativa à urbanização brasileira. Em seu estudo sobre a metropolização de São Paulo, Seabra (2004) mostra como que o urbano, como modo de vida, integrado simultaneamente na vida de bairro - 
espaços de representação - constitui-se como um processo a partir do qual redefine e incorpora os atributos do viver às dimensões do vivido, nível já relacionado ao mundo da mercadoria e às representações do espaço. Nesta simultaneidade oriunda da necessidade da reprodução ampliada do capital e, portanto, da modernização, o processo, como demonstra a geógrafa, é, necessariamente, espacial. Como expressa:

"Logo o urbano como modo de vida tem sua gênese na cidade histórica. É o social se constituindo onde cada indivíduo, cada trabalho, formando-se como parte de um todo, perde-se no horizonte propriamente individual porque se torna abstrato. No presente, o urbano se consuma na fragmentação do espaço e do tempo,..." (SEABRA, 2004,p.13-14)

Simultaneidade que se apresenta, no momento de reprodução crítica, e sempre crítica do mundo da mercadoria, por uma insuficiência do próprio espaço enquanto esta simultaneidade, sendo o mesmo subtraído de si mesmo como espaço para repor-se, enquanto tal no processo de reprodução, constituindo o que Carlos (2000) observou como o espaço amnésico a partir do tempo efêmero, isto é, espaço que, na necessária simultaneidade para a reprodução, sequer a memória social nele pode, sob o capitalismo financeiro, ser retida. O que se deriva, contraditoriamente, é que, nesta lógica avassaladora, o destruir e construir como produção expressa a preponderância do próprio espaço como condição, resultado e necessidade do Cotidiano enquanto reprodução global.

"Aqui, a fragmentação do espaço, imposta pela propriedade privada do solo urbano, se realiza também como fragmentação da vida social. O novo engole, incessantemente, as formas onde se inscreve o passado; sem referencial, a busca incessante do novo transforma a metrópole no instantâneo..." (CARLOS, 2000, p. 47).

Caberia ainda destacar como que no próprio processo de formação do espaço urbano, particularizado pelo desenvolvimento desigual do capitalismo, do qual o Brasil é parte constituinte, a forma da simultaneidade, como forma do urbano mesmo, acaba por se estabelecer como um elemento que conduz, por antecipação, à própria produção do espaço. Tese que destaca a simultaneidade como a própria identidade do espaço, que, nesta densidade temporal, se efetiva em seu transcurso histórico como produção espacial.

“A simultaneidade do urbano será a de se apropriar [de] momentos para a produção de seu espaço. O espaço da realização da riqueza na forma valor, monetária, sendo ele mesmo a constituição de formas de acumulação originária." (SILVA, 2005, p.20).

Destaca-se, assim, a simultaneidade posta na forma mercadoria, a partir da qual, o espaço, efetivação da densificação do tempo, se realiza como sua produção. A forma da simultaneidade aqui transparece como espaço antes mesmo do espaço se colocar como produção espacial. Lógica e história se relacionam a explicitar a densificação do próprio tempo como espaço.

As determinações espaciais, para Henri Lefebvre, ao se referirem aos sentidos da reprodução social, relacionam-se tanto a esta reprodução ou a este sentido, como também, ao conterem esta determinação, só a realizam na medida em que representam a diversidade daquilo que não são. Portanto, é no espaço e através do espaço que a sociedade se lê no reflexo de seu espelho, pois que, para Lefebvre, a imagem nítida do espelho é aquela que mostra o seu outro como se fosse o mesmo. Lembremos o destaque que o autor dá ao tecer suas digressões na Arquitetônica Espacial 20 , ao construir a idéia de que o espelho reflete, na imagem, aquele ou aquilo que está fora, de modo invertido. Vale lembrar que, neste momento, Lefebvre busca ressaltar que, no espelho, o lado direito, refletido, aparece como se fosse o esquerdo.

“ Le miroir? Cette surface pure et impure, presque matérielle, quasiment irréelle, fait apparaître devant l'ego sa présence mattérielle; 
elle suscite son inverse, son absence et son inhérence dans cet espace 'autre'. Sa symétrie s'y projetant, il I'y découvre et peut croire que 'ego' coïncide avec cet "autre", alors qu'il le représente, image inverse, où la gauche vient à droit, réflexion qui produit une différence extrême, répétition qui transforme le corps de l'ego en un fantôme obsédant. De sorte que I'identique est aussi I'absolument différent, et la transparence équivaut à I'opacitè." (LEFEBVRE,2000,p.-214-5)21.

Reflexão ou representação? Deste modo, - espaço passa a se constituir também, e necessariamente, a expressão reflexa da sociedade e, enquanto tal, representação da mesma, daquilo que ela não é como se isso fosse.

A tese sobre o espaço capitalista como o espaço de catástrofe do espaço perspectivo, denota, de modo contundente, a dimensão representativa que este espaço adquire e oferece na reprodução das relações sociais de produção, extremada na imponência da fachada por sobre as perspectivas que se referem à profundidade e expressam relações de unidade entre forma e conteúdo de sociabilidades prémodernas. Paul Klee, segundo o autor, revelou a catástrofe da perspectiva pelo seu estilhaçamento na hipérbole da fachada, através do cubismo. Bauhaus, mais do que o símbolo desta expressão espacial da modernidade, realizou, em algum grau, os sentidos do espaço no mundo moderno.

No pensamento lefebvriano, o espaço capitalista, portanto, na medida em que se integra como universalidade do mundo da mercadoria, deve não somente ser a mera reprodução ou funcionalidade posta sob as estratégias da reprodução, mas sim que deve conformar os discursos sobre a totalidade para efetivar a autonomia das partições e segmentações postas como pressuposto e resultado do mundo moderno, enquanto prática; a partir do que ganha um novo sentido a dimensão funcional estruturalista da/na reprodução social. Não se trata de negar o estruturalismo e o funcionalismo, mas de compreendê-los como representações de totalidade que, postos em sua autonomia autoreferenciada como totalidade, ganham estatuto prático na reprodução, na medida em que representam o possível como reprodução do presente 22 .

Destaca-se, portanto, a importância das representações no mundo moderno. Se as relações postas entre termos distintos tornamse possíveis porque resultam de contradições próprias do mundo da mercadoria, as mesmas estabelecem lógicas próprias, redutoras e reduzidas, circundam-se em estreitos planos da realidade na autonomia da exatidão que aí circunscrevem para representarem a não contradição da contradição que os colocou como efetividade. Mais do que isto, a representação, ao constituir símbolos aproximativos daquilo que não existe, a não ser como representação, intercala o resultado como algo já dado, simultaneidade que efetiva o sentido espacial que a modernidade aí assenta. Giannotti (1983), também destacara o sentido da antecipação que a representação traz ao processo social:

“Podemos fazer da relação social um pacto porque um indivíduo se reporta a outrem por intermédio dum objeto que carrega uma dimensão representativa, a antecipação duma ação a que deve corresponder uma reação de terceiros." (GIANNOTTI, 1983, p.59).

É com pertinência, portanto, que as representações do espaço ganham estatuto categorial na teoria espacial lefebvriana. Tratase, enfim, de, contraditoriamente, ser o espaço essa universalidade que, enquanto tal, reproduz, na forma de representação, a sua verdade como subsistema que se faz como totalidade. Contradição do espaço? Numa apreciação sobre a problemática espacial assim acentua Damiani (2004) a importância sobre o método:

"É preciso uma noção que coloque, francamente, os processos sociais de produção, na sua historicidade. É preciso ir em direção a uma concepção da produção do espaço, que exija mais do que a lógica formal." (DAMIANI, 2004,p. 84). 
Neste particular momento, pode-se afirmar que, na teoria lefebvriana a respeito do espaço, em sua perspectiva contraditória, põese o mesmo como o espelho, a partir do qual a sociedade se entende como tal. É na produção e reprodução espacial que, apropriando-se de temporalidades, ainda que na forma da propriedade, o espaço reflete - segundo aquela perspectiva do espelho já comentada a partir da Arquitetônica Espacial - a realidade que ele circunscreve.

Neste jogo de espelhos, a própria dimensão espacial da sociedade faz-se limitada à sua extensão concreta e palpável: representação do espaço como espaço..., mas que fundamenta a sua politização nas estratégias intervencionistas no próprio âmbito do que o autor chamou de a produção do espaço. Deste ponto de vista, a neutralidade espacial Lefebvre (1976) só pode se apresentar, para o autor, como uma representação do espaço como espaço. Enquanto universalidade, portanto, o próprio espaço subverte a si representando-se como sistema autonomizado, como totalidade fechada da realidade que o produz e o efetiva como unidade contraditória do/no mundo da mercadoria.

Lefebvre não traria esta correlação do espaço enquanto representação de si e da sociedade, necessidade do mundo da mercadoria, sem que se tivesse por traz a sua contribuição à teoria das representações. Vale ressaltar que, para não repetir o já exposto acerca das representações do espaço, as representações, em sua teoria correspondente, compõem-se como elementos formais a partir dos quais a unidade contraditória dos termos referentes se apresenta como identidade simples, dirimindo a percepção dos antagonismos e contradições que daí derivam. Desta maneira, o contrato, o casamento, o salário, dentre outros, são formas que subvertem a tensão da desigualdade pondo-a no plano das equivalências. Como observou atentamente José de Souza Martins ..."a função da forma é a de revestir de coerência aquilo que é contraditório e tenso. É, por isso, negação mediadora das relações que expressa" (MARTINS,1990,p.13). Em sua pesquisa sobre a expansão da metrópole através dos conjuntos habitacionais, Damiani (1992) ressalta como que a forma, tendo este sentido, estabelece-se na tensão aos conteúdos a ela referentes; supressora, instaura, numa metrópole que particulariza o movimento geral da reprodução, uma sociabilidade que não atinge o cotidiano, mas tão somente o infra-cotidiano.

"O cotidiano não é somente ordem imposta, ele é, no plano subjetivo, uma organização de vida assegurada. Quando o banal do dia a dia, como se alimentar, vestir-se, alojar-se, locomoverse, produzir, faz parte da vida de forma segura. Com esses tempos, atividades e espaços conquistados de maneira que parece definitiva. É a ordem diária da segurança material. Tendo cotidiano se dorme em paz. Lefebvre define o cotidiano, neste sentido, como algo entre o infracotidano e o supra-cotidiano, enquanto uma sorte de média social. “ (DAMIANI,1992, p.20).

No pensamento de Henri Lefebvre a forma da mercadoria, tal como Cotidiano, estende-se como domínio por todas as dimensões da sociabilidade fundada no mundo da troca e do valor. Daí a tese fundamental relativa à presença-ausência Lefebvre (1983). Há que se representar o ausente, efetivando-o como representação, para reproduzir o que está presente, tomando este tanto o sentido temporal como o sentido daquilo que está posto. Uma vez mais, mediação que embaralha a seqüência do tempo, realizando a efetividade do espaço como elemento determinante da modernidade.

Esta preocupação permeia o pensamento lefebvriano desde suas primeiras incursões a respeito da modernidade e não esteve ausente em sua interpretação a respeito das rupturas estabelecidas na passagem para a modernidade do feudalismo francês. Em seu estudo sobre as comunidades dos pirineus Lefebvre (1963) a perda da condição comunal, estabelecida numa luta contra o domínio feudal e contra a ampliação do mundo da troca e da 
equivalência, resulta no prevalecimento, através deste último, da inserção das representações efetivadas através da mediação monetária. Como o sentido é de ruptura e de passagem para as relações modernas trata-se de, assim, representar, pelo moderno, as relações comunais. A ritualização da assembléia geral prática costumeira -, a definição dos ofícios pelo montante monetário, dentre outros, é a expressão empírico-analítica de que as representações adquirem este papel mediático que suprime o tempo como seqüência. A simultaneidade posta pelas representações feudal e moderno ao mesmo tempo - expressam as representações e as mediações como efetividade do espaço. O costume, transmutado em direito costumeiro e este em direito, exacerbação da escrita - forma - sobre a palavra, realiza o plano das representações como elementos constituintes e efetivos da modernidade em seu transcurso mais ou menos violento, mas sempre como violação. O percurso temporal para a modernidade, portanto, é a posição do espaço como reprodução social.

"Le droit coutumier (ou prédroit) déjà fixè par des textes, c'est-à-dire réglant les rapports de la communauté organisée avec l'extérieur, avec les instances supérieures, et aussi avec ses propres organismes et représentants permanents.

Il s'agit, en fait, déjà d'un 'droit écrit' puisque stipulé par des textes. Mais il s'agit encore de coutumes rédigée après des événmemens ou changements, presque toujours avec l'illusion d'une nouvelle durée coutumière illimitée." (LEFEBVRE, 1963, p.140) ${ }^{23}$.

Neste ponto, o próprio espaço se põe como representação do espaço e a ilusão de concretude que daí deriva integra a tese lefebvriana de que o mundo da mercadoria passa a se constituir também pelo superdimensionamento do visual por sobre outros sentidos, o que resulta num embaralhar dos sentidos e da percepção filtrados como representação de conhecimento pela visualidade, contribuiindo a fundamentar o espaço como ilusão de concreticidade, ilusão espacial. Trata-se, certamente, da tese sobre a legibilidade espacial. O pressuposto é que neste subverter dos sentidos pelo visível, a relação entre objeto e conhecimento se reduz a linguagens particionadas que, em assim sendo, auto-referenciam-se conduzindo o real a um conjunto de sistemas e subsistemas que se auto-explicam. Aqui tudo aparece como linguagem ou linguagens, que passam então a conter, cada uma, a sua própria sintaxe. A verdade, mais uma vez, reduzida à exatidão, parece transparecer na medida em que as regras destas distintas, múltiplas e variadas linguagens, são meramente executadas. É como se a validade das regras sintáticas das múltiplas linguagens - que se efetivam como subsistemas fechados que se fazem como totalidade - fosse suficiente para expressar a verdade daquilo a que se referem. Resulta daí uma mera unidade, isto é, uma indistinção entre texto e contexto, donde o prevalecimento do texto, representando a si mesmo como contexto, retira, sem o expressar, a relação de inteligibilidade que se faz entre significante e significado. A linguagem, portanto, ao atingir este grau zero em relação aos seus referenciais, sendo ela referência de si mesma, estabelece a metalinguagem como instrumento de reprodução.

"Existe conflito entre a função referencial e a função metalingüística. Esta corrói e suplanta aquela. Quanto mais opaco se torna o referencial, mais cresce a importância da metalinguagem. Quando a linguagem e o discurso são tomados como referenciais, estamos no reino da metalinguagem. Operando no segundo grau (e às vezes no terceiro), a metalinguagem afasta e dissolve os referenciais. Reciprocamente, cada desaparecimento de um referencial anuncia a extensão de uma metalinguagem (ou da metalinguagem num setor particular), de modo que a metalinguagem substitui a linguagem, transferindo para si mesma os atributos de linguagem dotada de um referencial. Cada referencial que cai libera significantes soltos, destacados e, por conseguinte, disponíveis. A metalinguagem se apodera desses significantes $e$ 
os utiliza num emprego 'no segundo grau'. Esse emprego contribui para dissolver os referenciais, e a metalinguagem reina sob uma luz fria (o gênero cool)." (LEFEBVRE, 1991,p.140).

A teoria espacial lefebvriana, portanto, teve que desvendar esta ilusão espacial, isto é, mostrar que o espaço não se oferece ao mundo moderno como um subsistema a partir do qual se pode daí derivar uma linguagem ou metalinguagem, uma sintaxe, de modo que o mesmo contemple, através dele, uma legibilidade do social.

"Autrefois prédominant, le trait 'nature' s'estompe et devient subordonné. Alors qu'inversement le caractère social de l'espace (les rapports sociaux qu 'il implique, qu'il contient et dissimule) commencent à l'emporter visiblement. Ce trait caractéristique, la visibilité, n'entraîne portant pa la lisibilité des rapports sociaux inhérents. L'analyse de ces rapports, au contraire, devient difficile, à ce point qu' il lui arrive d'avoisiner le paradoxe ". (LEFEBVRE, 2000, p. 100$)^{24}$.

Isto só é possível como ilusão ou representação espacial, daí o paradoxo entre a importância do espaço no mundo moderno e a sua presença como representação daquilo que não é. Contradição do espaço? Em termos relativos à relação entre forma e conteúdo, trata-se do desvendamento, em sua teoria, da autonomização das formas. O espaço se constitui como um instrumento na medida em que delimitado como objeto desta ou daquela ciência, sendo o planejamento e a burocracia formas particionadas do conhecimento que fazem do espaço esta metalinguagem, daí a tese, uma vez mais, da não neutralidade e da politização do espaço.

Os espaços de representação, dimensão do qualitativo e do concreto, passam a se constituir como momentos necessários para a efetivação das representações do espaço, subversão que integra os sentidos da modernidade. Portanto, a ausência de estilo como o estilo da modernidade, realidade que se reproduz a partir da desintegração da relação entre ética, estética e estilo, resultando em estetismos, revigora o romantismo a buscar no passado espaços de representação que se reproduzam no presente como mundo da mercadoria. A moda e o demodé, o espaço de consumo, mas, especialmente, o consumo de espaço, explicitam a dimensão superficial e sem profundidade, mas necessária, na e para a constituição da modernidade.

O espaço, ao conter esta universalidade do real enquanto modernidade, repõe as dimensões do formal como determinantes. Explicitemos... Para Henri Lefebvre a reprodução das relações sociais de produção, ainda que criticamente e por serem críticas, fazem-se a partir de determinações espaciais, como comentado mais acima. Disto deriva que o plano das lógicas, redutoras, efetiva-se, no mundo da mercadoria, como aquela identidade, pela mediação, do antes e do depois. Deste ponto de vista, elas antecipam o resultado que, enquanto efetividade, fazem-se como concepção de mundo. O plano do concebido, portanto, se se integra à esfera das estratégias e do político, não deixa de ser uma forma da totalidade social exacerbada pelo mental: razão como instrumento da reprodução. Deve-se ressaltar, ainda, que as concepções devem conter outros níveis da realidade na medida em que tendem e dentro do possível o fazem - , contraditoriamente, a reduzi-las à própria identidade da concepção. Daí o sentido da folha em branco do arquiteto e da tábula rasa que o concebido adquire no pensamento de Henri Lefebvre. Trata-se de uma unidade das distintas dimensões ou níveis espaciais da realidade determinados pela negatividade posta como violência. O concebido, portanto, realiza-se triadicamente (com o percebido e o vivido, outras duas dimensões do moderno enquanto espaço) porque, sendo esta negatividade específica a sua identidade, detém os outros termos da relação como ausências. Daí a sua aparente independência e isolamento em relação à realidade. Esta específica negatividade do concebido, pode-se dizer, constitui a sua própria determinação, segundo a apreciação que se faz do pensamento lefebvriano. Como tal, trata-se 
do império das formas e da razão postas como instrumento e como verdade de per si. É, na interpretação do autor, o plano do equilíbrio como representação, restaurar de um Apolo a marejar indelével sobre a turbulência de um oceano dionisíaco, intempestivo. A importância de Niesztche para a compreensão do mundo moderno no pensamento de Henri Lefebvre está expressa em algumas de suas obras fundantes, das quais pode-se citar Lefebvre (1983) e (1987). Vejamos uma passagem:

“La 'perdida de identidad'? Es lo trágico de la situación. Alienación? Efecto de una alienación? No. Este juicio ya no basta. La 'perdida de identidad', condición de la metamorfosis, puede rechazarse. Entonces triunfa la identidad, es decir, la repetición. Al ser aceptada " la pérdida de identidad como vía peligrosa de una metamorfosis $y$, por tanto, de una diferencia, triunfa la embriaguez dionisíaca. La vida en el grado más elevado hace uso de los dos procedimientos. La embriaguez dionisíaca por sí sola arrastra hacia la aventura sin ley, la droga, el erotismo, el abandono instantáneo y la locura, y al mismo tiempo hacia la desintegración de sí mismo y la persecución de la trascendencia. La memoria y el conocer permitem frenar, controlar hasta cierto punto la metamorfosis, a riesgo de impedirla. Apolo, considerado aisladamente, implica el peligro de otra disolución. La unida en el contraste y el enfrentamiento de las dos potencias: esa es la vía, según Nietszche." (LEFEBVRE, 1983, p. 273).

Nesta representação apolínea, contudo, é que se faz como possível a efetividade abstrata. Fala-se, enfim, das estratégias espaciais, isto é, das formas da mediação, a integrarem a produção do espaço. Neste percurso, as concepções espaciais forjam o espaço naquele simples sentido do espaço representado como espaço. O planejamento, âmbito prático das concepções espaciais, adquire, portanto, uma importância não negligenciável na produção do espaço moderno.

A unidade posta no espaço como dimensão determinante do mundo da mercadoria é, ao mesmo tempo, o desenvolvimento das partições estabelecidas como condição e pressuposto do mundo moderno, ressaltadas já por Marx em $A$ assim chamada acumulação primitiva. O superdimensionamento do espaço, ou se se quiser, da importância do espaço na reprodução, na medida em que há uma redução do tempo ao espaço, realiza nesta unidade as segmentações.

Dada a prevalência do mental por sobre o social, ou ainda, do concebido sobre o vivido, resultado da extensão do mundo do trabalho como não trabalho, as relações de integridade de elementos espaciais se desdobram como partições elementares, perdendo a relação que entre elas se torna possível estabelecer, isto ao menos no âmbito da consciência. Forma, função e estrutura, destituídas de suas relações intrínsecas, na modernidade, dado a prevalência acima citada, destituem, nesta unidade não mais posta, a percepção como relação integrada entre sujeito e objeto. A expressão desta integridade que compõe o pensamento de Henri Lefebvre se dá nas Termas romanas, onde forma espacial, vinculada a uma função que, necessariamente, recorre a uma estrutura que é o antes (a natureza donde está o possível como Termas), o durante (as Termas propriamente) e o depois (reincidência da unidade expressa nas linhas curvas que integram esta totalidade para além da mera função, retirando desta a possibilidade de prevalência) está sempre a explicitar um mundo em sua integridade, seja como objeto, seja como consciência deste objeto. Concebido e percebido, enfim, realizam-se como vivência, desfrute. Não se trata de uma idealização do mundo romano, mas, especialmente, de uma incursão reflexionante naquilo que compõe o sentido de uma unidade "apenas" representada no mundo moderno. Se este percurso idealizante se faz em relação ao mundo romano, a teoria lefebvriana é muito mais uma explicitação do moderno do que um possível desvirtuamento do que ali, nas Termas, poderse-ia expressar. A regressão lefebvriana é sempre um pulsar de consciência sobre o presente como devir e não uma estrita explanação sobre o passado. 
“ L'habitus grec de l'espace, inséparablement social et mental, autorisait-il la formulation des concepts essentiels: forme, fonction, structure? Certainement, puisque la philosophie s'engage dans cette formulation explicite et que le philosophe s'en charge, mieux encore Aristote que Platon. Chez celui-ci, I'unidité resplendit dans la transcendence ontologique. Chez Aristote, elle devient théorie du discours, du classement, de la cohérence. A peine franchi le seuil de la formaulation, les concepts se dissocient; le conçu se sépare du vécu e L'habitus de I'intuits, brisant leur unityé présupposée. Par contre, dans l'intuitus romain, la subordination de la forme, de la strutcture, de la fonction enchaque chose (pas de meilleur exemple que les Thermes) à un principe à la fois matériel (un besoin) et juridicitionnel (civique) qui en fixe I'usage social, laisse pour ainsi dire du jeu à I 'unité. L'espace romain s'encombrera d'objets (le forum) mais sera productif. Et plus libre, ce dont témoigne un plus large emploi des coubures. L'uynité de la Loi, du Droit, de la Proprieté, de la Ville-État, parce que vécue et percue mieux que conçue, évitera la cassure irrémédiable. Le besoin, à Rome, aparaît comme un caractère presque total: les Thermes comme la Villa contiennent tout ce que demanden les corps et les esprits des libres (et riches) citoyens." (LEFEBVRE, 2000, p.277) 25 .

O percebido, mesmo na fragmentação como mundo moderno, termo médio entre a concepção e o vivido, restaura a tríade como possibilidade, na medida em que se integra como necessidade racional para a realização na partição entre mental e social, entre forma, função e estrutura - da própria razão como instrumento. Se aí o vivido aparece como o âmbito da supressão pela forma que prevalece como concebido, é nele que as contradições se expressam de forma mais explícita, são contradições tanto entre a forma e o conteúdo, como contradições do conteúdo para consigo mesmo. Ressalte-se, portanto, que em Lefebvre os termos, embora segmentados na prática social, são sempre formas particulares de reunião da tríade que, assim posta como espaço, realizam nesta relação o moderno como prática espacial. Isto é, cada um dos termos realiza-se na relação com o outro como espaço, e um espaço, aquele da modernidade. Daí a noção de prática espacial permear um sentido de unidade nos distintos termos. Noção que, posta na determinação lógica do mundo moderno, implicará em relações de inclusãoexclusão que o espaço, enquanto tal, realiza de modo mais acabado.

Por fim, a importância do estudo da modernidade a partir do pensamento de Henri Lefebvre não só traz reflexões e aponta caminhos profícuos como contribui para a construção de um conhecimento que tome o espaço como uma categoria filosófica, mais do que um mero vocábulo. Neste ponto, a Geografia ganha uma tarefa e um papel fundamental, na medida em que a compreensão do espaço e da modernidade constituem parte integrante de seu objeto enquanto ciência. Se a sociedade moderna se efetiva através do que o autor considerou como prática espacial, a importância de sua obra para a Geografia está posta, não como algo dado, mas como desafio do e para o conhecimento. 


\section{Notas}

1 Agradeço ao Prof. Dr. Sérgio Martins, do Instituto de Geociências da Universidade Federal de Minas Gerais, pelas sugestões e leitura crítica.

2 O debate sobre feudalismo ou capitalismo no período escravista e colonial brasileiro pode ser visitado em Prado Jr. (1977).

${ }^{3}$ A tese sobre o sentido da colonização, defendida por Caio Prado Jr., apresenta-se como um marco teórico divisor sobre o debate relativo ao feudalismo ou capitalismo como sociabilidade determinante da formação brasileira e pode ser visto em: Prado Jr. (1999).

4 Trata-se do título do capítulo XXIV do primeiro volume de O Capital de Karl Marx (1997).

5 "A importância das mediações (vermittlugen, em Hegel) reais e não somente mentais (intelectuais) não pode se subestimar. Na mediação - do dinheiro à imagem nas mídias modernas - se desenvolvem as propriedades de uma só vez materiais e formais das coisas. Em Hegel, a mediação não se define somente por isso de onde provêem: origem, causa histórica, "terminus quo". Ela se define também pelo sentido e pelo objetivo, pelo fim e pelo "terminus ad quem", mas sobretudo pela operação que embaralha o fim e o meio o original e o terminal. O utensílio (instrumento) serve de intermediário (mediador) entre a atividade e a mão do trabalhador, de um lado, as matérias trabalhadas do outro. Ora, os gestos dos trabalhadores e os trabalhadores eles mesmos mudam, as matérias a mesma coisa." (LEFEBVRE, 1977, p.-64-65).

6 Cf: Marx (1997).Uma apreciação sobre relação entre capital circulante e o espaço pode-se observar em Alfredo (2005).

7 “ Esse espaço seria ele abstrato? Sim, mas ele também seria "real", como a mercadoria e o dinheiro, essas abstrações concretas. Seria ele concreto? Sim, mas não do mesmo modo que um objeto, um produto qualquer. (...)"(LEFEBVRE, 2000, p.-35-36).

8 Refletimos sobre essa tese Santos (1977) em Alfredo (2005).

9 Esta tese está explícita em algumas de suas obras, considero aqui portanto duas publicações: Santos (1991) e uma publicação parcial desta mesma obra: Santos (2002).

10 Cf. Giannotti (2000).

11 A respeito dessa tríade (concebido, percebido e vivido) far-se-á uma abordagem ao longo do artigo, quando da análise sobre a problemática espacial em $A$ produção do espaço de Henri Lefebvre, mais à frente.

12 "As forças produtivas (natureza, trabalho e organização do trabalho, técnicas e conhecimentos) e, bem entendido, as relações de produção, têm um papel - a determinar na produção do espaço." (LEFEBVRE, 2000, p.57).

13 Uma reflexão sobre essa perspectiva teórica de Henri Lefebvre pode ser encontrada em Martins (1999).

${ }^{14} \mathrm{Cf}$ : Lefebvre (2000).

${ }^{15}$ Deve-se, contudo, distinguir aqui realidade urbana da noção sociedade urbana, cujo sentido é outro e está expresso em $A$ revolução urbana. Realidade urbana, expressa aqui, apenas se refere ao crescimento das grandes cidades ao longo do XIX e XX, como se referenciou no texto.

${ }^{16} \mathrm{Cf}$ : Lefebvre (1972); (1983); (1972).

${ }^{17} \mathrm{O}$ desenvolvimento desigual como uma questão de método para a análise da expansão do capitalismo pode ser observada em Lenin (1982).

18 Confrontar também, Martins (1993).

19 “Mais que invariâncias ou constâncias, essa passagem incessante da temporalidade (sucessão, encadeamento) à espacialidade (simultaneidade, sincronização) define toda atividade produtora" (LEFEBVRE, 2000,p. 87).

20 Trata-se do título do terceiro capítulo de Henri Lefebvre, La production de l'espace, Paris, Anthropos, 2000.

21 "O espelho? Essa superfície pura e impura, quase material, quase irreal, faz aparecer diante do ego sua presença material, ela suscita seu inverso, sua ausência e sua inerência nesse espaço "outro". Sua simetria aí se projetando, ele aí descobre e pode crer que "ego" coincide com esse "outro", então que ele o representa, imagem invertida, onde a esquerda se torna a direita, reflexão que produz uma diferença extrema, 
repetição que transforma o corpo do ego em um fantasma obsessivo." (LEFEBVRE, 2000,p.214-5).

22 Sobre Henri Lefebvre e o estruturalismo vale a consulta Lefebvre (1973); (1967).

"O direito costumeiro (ou pré-direito) desde já fixado pelos textos, isto é, regulando as relações da comunidade organizada com o exterior, com as instâncias superiores, e assim com seus próprios organismos e representantes permanetentes. Trata-se, de fato, desde já de um 'direito escrito' pois que estipulado pelos textos. Mas trata-se ainda de costumes redigidos após acontecimentos ou mudanças, quase sempre com a ilusão de uma nova duração costumeira ilimitada." (LEFEBVRE,1963, p.140).

23 "Anteriormente predominante, o traço 'natureza' rompe-se e se torna subordinado. Então que, ao contrário, o caráter social do espaço (as relações sociais que ele implica, que ele contém e dissimula) começa a tomar importância visivelmente. Esse traço característico, a visibilidade, não reúne portanto a legibilidade das relações sociais inerentes. A análise dessas relações, ao contrário, torna-se difícil, a ponto que se chega a avizinhar de um paradoxo. (LEFEBVRE, 2000, p.100).
24 “ O habitus grego do espaço, inseparavelmente social e mental, autorizaria a formulação de conceitos essenciais: forma, função, estrutura? Certamente, pois que a filosofia se engaja nessa formulação explícita e que a filosofia se encarrega, melhor ainda Aristóteles que Platão. Nesse, a unidade resplandece na transcendência ontológica. Em Aristóteles, ela se torna teoria do discurso, da classificação, da coerência. A pena atravessa o limite da formulação, os conceitos se dissociam; o concebido se separa do vivido e o habitus do intuitus, quebrando sua unidade pressuposta. Pelo contrário, no intuitus romano, a subordinação da forma, da estrutura, da função em cada coisa (sem melhor exemplo que as Thermas) a um princípio de uma só vez material (uma necessidade) e jurídico (cívico) que fixa o uso social, deixa, por assim dizer, o jogo à unidade. O espaço romano se preencherá de objetos (o forum) mas será produtivo. E mais livre, o que então testemunha um mais amplo emprego das curvas. A unidade da lei, do Direito, da Propriedade, da Cidade - Estado, porque vivido e percebido melhor que concebido, evitará a quebra irremediavél. A necessidade, em Roma, aparece como uma característica quase total: as Thermas como a cidade que contém tudo o que demandam os corpos e os espíritos dos (ricos) e livres cidadãos. (LEFEBVRE, 2000, p. 277).

\section{Bibliografia}

CARLOS, Ana Fani Alessandri, Uma leitura sobre a cidade, In: Cidades. Grupos de Estudos Urbanos GEU: Presidente Prudente, Vol. 1, n. 1, 2004, (pp.11-30).

CARLOS, Ana Fani Alessandri, Espaço e tempo da vida cotidiana na metrópole: Livre - Docência, Geografia, FFLCH-USP, SP, 2000, 380p.

CARLOS, Ana Fani Alessandri, "O consumo do espaço". In: CARLOS, Ana Fani Alessandri (orga.), Novos Caminhos da Geografia: SP, Contexto, 1999, (pp.173-186).

DAMIANI, Amélia Luisa, A Cidade (Des) Ordenada. Concepção e Cotidiano do Conjunto Habitacional Itaquera I: Doutorado, Geografia, FFLCH-USP, SP, 1992, 358p

DAMIANI, Amélia Luisa, “O lugar e a produção do cotidiano". In: CARLOS, Ana Fani Alessandri (orga ${ }^{\text {.) }}$, Novos Caminhos da Geografia: SP, Contexto, 1999, (pp.161-172).

DAMIANI, Amélia Luisa, "A propósito do espaço e do urbano: algumas hipóteses", In: Cidades. Grupos de Estudos Urbanos - GEU: Presidente Prudente, Vol. 1, n. 1, 2004, (pp.79-95).

GIANNOTTI, José Arthur, Trabalho e Reflexão. Ensaio para uma dialética da sociabilidade: SP, Brasiliense, 1983, 379p.

GIANNOTTI, José Arthur, Marx. Vida e Obra, Porto Alegre, LP\&M, 2000, 188p.

GIANNOTTI, José Arthur, Certa herança marxista. SP: Companhia das Letras, 2000, 333p.

HARVEY, David, Condição pós-moderna. Uma pesquisa sobre as origens da mudança cultural. SP, 
Loyola, 1992, 349p.

LEFEBVRE, Henri, Éléments de Rithimanalyse. Intriduction à la connaissance des rythmes. Paris: Silepse, 116p.

LEFEBVRE, Henri, A vida Cotidiana no Mundo Moderno. São Paulo: Ática,1991, 216p.

LEFEBVRE, Henri, Nietzsche. México: Fondo de Cultura Económica, 1987, 319p.

LEFEBVRE, Henri, Une pensée devenue monde... Faut-il abandonner Marx? Paris: Fayard, 1980, 263p.

LEFEBVRE, Henri, La revolución urbana. Madrid, Alianza Editorial, 1983, 198p.

LEFEBVRE, Henri, La vallée de Campan. Étude de sociologie rurale. Paris: Presses Universitarie de France, 1963, 220p.

LEFEBVRE, Henri, La presencia y la ausencia. Contribución a la teroía de las representaciones. México, Fondo de Cultura Económica, 1980, 277p.

LEFEBVRE, Henri, La production de I'espace. Paris: Anthropos, 1974, 485p.

LEFEBVRE, Henri, L'ideologie structuraliste, Paris: Anthropos, 1971, 251p.

LEFEBVRE, Henri, O pensamento marxista e a cidade. Lisboa: Ulissea, 1972, 173p.

LEFEBVRE, Henri, Hegel, Marx, Nietzsche ou o reino das sombras. Lisboa: Ulissea, 1976, 291p.

LEFEBVRE, Henri, Critique de la Vie quotidienne. Paris: Ed. L'Arche, 1961.

LEFEBVRE, Henri, Espacio y Politica. Barcelona: Peninsula, 1976, 157p.

LEFEBVRE, Henri (group de Navarrenx), Du contrat de Citoyenneté. Paris: Syllepse e Perscope, 1990, $382 p$.

LEFEBVRE, Henri, Mas alla del estructuralismo. Buenos Aires: La Pléyade, 1973, 203p.

LEFEBVRE, Henri, Tiempos equívocos. Barcelona: Kayrós, 1975, 256p.

LEFEBVRE, Henri, Introdução à modernidade. Rio de Janeiro: Paz e Terra, 1969, 442p.
LEFEBVRE, Henri, Le droit à la ville suivi de Espace et politique. Paris: Anthropos, 1968 e 1972, 281p.

LEFEBVRE, Henri, Contribuición a la estetica. Buenos Aires: La pléyade, 1971, 157p.

LEFEBVRE, Henri, De L'Etat. Le mode de production étatique. Vol. 3. Paris, Unión Generale d'editons, 1977, 375p.

LEFEBVRE, Henri, La survie du capitalisme. La reproduction des rapports de production. Paris: Anthropos, 1973, 273p.

LEFEBVRE, Henri e outros," Reflexões sobre o Estruturalismo e a História" In: ESCOBAR, Carlos Henrique, $O$ método estruturalista. Rio de Janeiro: Zahar, 1967, (pp.80-103).

MARTINS, J osé de Souza, Henri Lefebvre e o retorno à dialética. SP: Hucitec, 1996, 151p.

MARTINS, José de Souza, O cativeiro da terra. SP: Hucitec, 1990, 157p.

MARTINS, Sérgio, A cidade "sem infância" no universo pioneiro de Chapadão do Sul (MS). São Paulo: (Mestrado, Geografia), FFLCH-USP, 1993, 215p.

MARTINS, Sérgio, "A cidade "sem infância:" a produção do espaço no mundo da mercadoria." Boletim Paulista de Geografia. SP, 1996, (pp. 23-47).

MARX, Karl, O Capital. O processo de produção do capital. Vol. II, Tomo II, Trad. de Regis Barbosa e Flávio R. Kothe. São Paulo: Nova Cultural, 1988, 294p.

MARX, Karl, Elementos Fundamentales para la Critica de la Economia Politica . (Grundrisse) 1857 1858. Trad. Pedro Scaron- Esp. vol. I, $17^{\text {a }}$ ed. México, Argentina, Espanha Colombia: Siglo Vinteuno,1997, $500 p$.

MARX, Karl, Elementos Fundamentales para la Critica de la Economia Politica . (Grundrisse) 1857 1858. Trad. Pedro Scaron Esp. vol. II, $13^{a}$ ed. México, Argentina, Espanha Colombia: Siglo Vinteuno,1997, $493 p$.

MARX, Karl, Elementos Fundamentales para la Critica de la Economia Politica . (Grundrisse) 1857 1858. Trad. Pedro Scaron Esp. vol. III. $11^{a}$ ed. México, Argentina, Espanha Colombia: Siglo Vinteuno,1998, 
$349 p$.

PRADO JR., Caio, Formação do Brasil Contemporâneo.

Colônia. São Paulo: Brasiliense, 1999, 390p.

PRADO JR., Caio, A revolução brasileira. São Paulo: Brasiliense, 1977, 267p.

PRITCHARD, E. E. Evans, Os Nuer, Uma descrição do modo de subsistência e das instituições políticas de um povo nilota. São Paulo: Perspectiva, s/d, 275p.

SANTOS, Milton, El presente como espacio, Trad. Raymundo Martínez Fernandez, $1^{\text {a }}$ ed., México: Universidad Nacional Autónoma de México, 2002, 36p.

SANTOS, Milton, Pensando o espaço do homem. São Paulo: Hucitec, 1991, 63p.

SANTOS, Milton, Por uma Geografia nova. São Paulo: Hucitec e Edusp, 1978, 236p.

SANTOS, Milton, A natureza do espaço. Técnica e tempo, razão e emoção. SP: Hucitec, 1996, 308p.
SANTOS, Milton, "Sociedade e espaço: A formação social como teoria e como método" In: Boletim Paulista de Geografia, Associação dos Geógrafos Brasileiros, Seção São Paulo, n. 54, (pp.81-101.)

SEABRA, Odette Carvalho de Lima, "O pensamento de Henri Lefebvre e a Geografia" In: Boletim Paulista de Geografia, Associação dos Geógrafos Brasileiros, Seção São Paulo, n. 74, 1996 (pp.07-21.)

SEABRA, Odette Carvalho de Lima, Urbanização e fragmentação. Cotidiano e vida de bairro na metamorfose da cidade em metrópole a partir das transformações do Bairro Limão, SP, (Livre Docência), Geografia, FFLCH-USP, SP, 2003.

SILVA, Ana Cristina Mota, Do "entesouramento" à acumulação urbana. A produção do espaço de Fortaleza no século XIX, (Doutorado, Geografia). São Paulo: FFLCH-USP, SP, 2005, 450p.

SOHON-RETHEL, Alfred, Trabalho espiritual e corporal. Para a epistemologia da história ocidental, Trad. Cesare Giuseppe Galvan, mimeo, s/d, 101p. 
